\title{
Diversity of Endophytic Bacteria in Hybrid Maize Seeds With Genetic Correlation and the Strain of Bacillus Mojavensis Isolated as a Potential Microorganism Capable of Vertical Transmission
}

\section{Xianyu Wu}

USTB: University of Science and Technology Beijing

Zhishan Wang

USTB: University of Science and Technology Beijing

Ruyang Zhang

BAAFS: Beijing Academy of Agriculture and Forestry Sciences

Tianjun Xu

BAAFS: Beijing Academy of Agriculture and Forestry Sciences

Jiuran Zhao

BAAFS: Beijing Academy of Agriculture and Forestry Sciences

Yang Liu ( $\square$ ly81150@163.com )

USTB: University of Science and Technology Beijing https://orcid.org/0000-0003-3261-7243

\section{Short Report}

Keywords: Maize seed, Endophytic bacteria, Diversity, RAPD molecular typing, Bacillus mojavensis

Posted Date: January 19th, 2022

DOI: https://doi.org/10.21203/rs.3.rs-1182513/v1

License: (c) (1) This work is licensed under a Creative Commons Attribution 4.0 International License.

Read Full License 


\section{Abstract}

The diversity of endophytic bacteria in the progeny is related to the parental lines. In this study, the traditional separation method was used to study the dominant endophytic bacteria of the shared paternal line and its pollen, different maternal lines and their F1 progeny. And the results showed that the dominant endophytic bacteria in maize seeds and the pollen were Bacillus and Pantoea. The Bacillus diversity of the progeny JMC121 and JN728 were the same as both the paternal line and the maternal line, including Bacillus subtilis, Bacillus velezensis, Bacillus mojavensis, and Bacillus licheniformis. The Bacillus subtilis and Bacillus velezensis in JN828 were the same as both the paternal line and the maternal line, while Bacillus licheniformis was only the same as the paternal line. Through the RAPD molecular typing, there was the same strain of Bacillus mojavensis existed in the paternal line J2416, the pollen and the progeny JN728, this meant that the paternal line passed its dominant endophytic bacteria to the progeny might through pollen in vertical transmission. This study showed that the dominant endophytic bacteria in maize seeds and the pollen were Bacillus, and the diversity of F1 progeny was related to both the paternal line and the maternal line.

\section{Introduction}

Maize is one of the most widely planted cereals in the world, and the planting area in China reaches more than 40 million hectares (Singh et al., 2019). Its production and development will promote the national economy and improve people's living standards (Yang et al., 2020). Since the beginning of the 20th century, to satisfy society's demand, maize breeding began to develop. For the demand for yield, a variety of biotechnologies such as cell engineering, genetic modification, and molecular markers have been applied to improve maize genes, improve maize quality and increase maize yield (Singh et al., 2020). In recent years, some researches have turned the direction of maize breeding to the direction of its microorganisms.

Plant endophytic bacteria are a kind of microorganisms that are symbiosis in plants and have no harmful effects on plant growth and development (Afzal et al., 2019). As a medium for carrying and transmitting plant genetic information, plant seeds also contain abundant endophytic bacteria resources (Wang et al., 2021). Santos et al. (2021) found that the germination rate of seeds with surface disinfection was significantly lower than that of the control group. The endophytic bacteria in the seeds coordinated the microbial balance of the seeds and promoted corn germination and seedling growth. The interaction between plants and microorganisms is the core of the circulation of nutrients in nature. Several studies have shown that endophytes induce beneficial effects in plants through many complex biochemical signal processes (Singh et al., 2020). The mechanism of action mainly includes two aspects. The first is the production of plant growth regulators for each stage of plant growth, and the second is to regulate various biochemical molecular reactions by secreting effector molecules and secondary metabolites (Singh et al., 2019). Endophytes interact with plants by producing various substances, promoting plants to absorb nutrients more effectively, increasing plant resistance to biological stress, and promoting plant growth and development (Taulé et al., 2021). 
In recent years, researches on plant bacteria have increased day by day. But there are few researches on maize microorganisms and most mainly focus on the research of root microorganisms. The dominant endophytic bacteria in maize seeds include Pantoea, Bacillus, Burkholderia, Enterobacter, Shigella, Pseudomonas, etc. (Bodhankar et al., 2017; Liu et al., 2020). Vertical transmission across generations has a profound impact on plant ecology. However, few studies are linking the diversity of endophytic bacteria in maize seeds with generational transmission, and most studies tend to be female parents (Santos et al., 2021). Based on the traditional separation method, this study found that Bacillus and Pantoea were the dominant bacteria of maize and the pollen at the genus level. And the diversity of endophytic bacteria in F1 progeny was related to both the maternal line and the paternal line. Through further RAPD molecular typing, the same strain of dominant endophytic bacteria Bacillus mojavensis was found in the paternal line, the pollen, and the progeny JN728.

\section{Materials And Methods}

\section{The source of Maize seeds and anther sample}

Samples used in this study were three maize families which had the common paternal line, respectively paternal line Jing 2416 (J2416) and its anther, the maternal line Jing 72462 (J72464) and its progeny Jing MC121 (JMC121), the maternal line Jing MC01 (JMC01) and its progeny Jingnongke 728 (JN728), and the maternal line Jing 88 (J88) and its progeny Jingnongke 828 (JN828) 『as shown in Figure 1. Seven maize seeds samples and one anther sample were collected from the southern propagation base of the Maize Research Center of Beijing Academy of Agricultural and Forestry Sciences in Sanya City, Hainan Province in March 2021, and then stored at $4{ }^{\circ} \mathrm{C}$.

\section{Sample surface sterilization and treatment}

Took $10 \mathrm{~g}$ maize seeds (or anthers) and rinsed with sterile water for 4-5 times, first soaked in $70 \%$ ethanol solution for 3 minutes, then soaked in sodium hypochlorite solution with a $\mathrm{Cl}^{-}$mass concentration of 250 $\mathrm{mg} / \mathrm{L}$ for 5 minutes, and finally soaked with $70 \%$ ethanol solution for $30 \mathrm{~s}$, and then rinsed with sterile water 5-7 times, took $120 \mu \mathrm{L}$ of the last rinse liquid and coated plate, and then incubated at $32^{\circ} \mathrm{C}$ for $24 \mathrm{~h}$. If there was no microbial growth, the surface was sterilized completely (Wang et al., 2021).

\section{Separation of endophytic bacteria from maize seeds and pollen}

The separation of endophytic bacteria in the sample adopted the traditional separation method. For each sample, grounded sterilized maize seeds and weighed $2 \mathrm{~g}$ ground powder in a centrifuge tube and diluted in a gradient. Took $100 \mu \mathrm{L}$ of three gradient dilutions of $10^{-3}, 10^{-4}$, and $10^{-5}$ and coated on LB and PCA medium for cultivation. Placed it in a constant temperature incubator at $32^{\circ} \mathrm{C}$ for $24 \mathrm{~h}$; Peeled off the shell of the anthers to collect pollen, weighed $1 \mathrm{~g}$ pollen and diluted gradients, coated with gradients $10^{-1}, 10^{-2}$, and $10^{-3}$ to LB and PCA medium. Placed it in a constant temperature incubator at $32^{\circ} \mathrm{C}$ for $24 \mathrm{~h}$. According to the colony morphology (including surface gloss, transparency, size, color, shape, edge neatness, etc.), selected representative monoclonal colonies, and stored at $4^{\circ} \mathrm{C}$ after purification. 


\section{Identification of endophytic bacteria in the sample}

The endophytic strains were identified based on 16S rRNA and gyrA gene phylogenetic analysis. The bacterial genomic DNA kit was used to extract endophytic bacterial DNA from the sample. Used forward primer 27F (5'-AGAGTTTCATCTGGCTCAG-3'), reverse primer 1492R (5' -GGTTACCTTGTTACGACTT-3') and forward primer gyrA-F (5'-CAGTCAGGAAATGCGTACGTCTT-3'), reverse primer gyrA-R (5'-

CAAGGTAATGCTCCAGGCATTGCT-3') to amplify and sequence the target gene. The reaction process was pre-deformation at $95^{\circ} \mathrm{C}$ for $5 \mathrm{~min}, 35 \mathrm{cycles}\left(95^{\circ} \mathrm{C}\right.$ for 1 minute, $55^{\circ} \mathrm{C}$ for $1 \mathrm{~min}, 72^{\circ} \mathrm{C}$ for $1 \mathrm{~min}$ ), and finally $72^{\circ} \mathrm{C}$ for $10 \mathrm{~min}$. The reaction volume was $50 \mu \mathrm{L}$. Submitted all these sequences of the endophytic bacteria to NCBI to obtain the accession numbers.

\section{RAPD molecular typing of endophytic bacteria}

After the identification of 16S rRNA and gyrA gene, it was found that Bacillus was the main group in maize seeds, including Bacillus subtilis, Bacillus mojavensis, Bacillus velezensis and Bacillus licheniformis. Based on the taxonomic status, it assumed that the endophytic bacteria were passed from the paternal line to progeny. RAPD molecular typing technology was used to identify whether these microorganisms were the same strain, and to provide substantive evidence for whether they could be passed from the paternal line to progeny. The primers used were OPA-02 (5'-TGCCGAGCTG-3'), OPA-18 (5'AGGTGACCGT-3'), OPL-07 (5'-AGGCGGGAAC-3'), OPL-16 (5'-AGGTTGCAGG-3'), and OPM-05 (5'GGGAACGTGT-3') (Lefevre et al. 2016). The reaction process was pre-denaturation at $95^{\circ} \mathrm{C}$ for $5 \mathrm{~min}, 45$ cycles $\left(94^{\circ} \mathrm{C}\right.$ for $1 \mathrm{~min}, 55^{\circ} \mathrm{C}$ for $1 \mathrm{~min}, 72^{\circ} \mathrm{C}$ for $2 \mathrm{~min}$ ), and finally $72^{\circ} \mathrm{C}$ for $10 \mathrm{~min}$. The PCR volume was $20 \mu \mathrm{L}$. After amplification, $10 \mu \mathrm{L}$ PCR products were taken and analyzed by $1 \%$ agarose gel electrophoresis and then observed and analyzed by the gel imager (Wu et al., 2021).

\section{Results}

\section{Diversity analysis of endophytic bacteria in maize seeds and the pollen}

Seven kinds of maize seeds and one kind of maize pollen were used to separate endophytic bacteria by the traditional method. After 16S rDNA identification, 6 strains of Bacillus were isolated from the paternal line J2416, and 19 strains of Bacillus were obtained from the pollen. 12 strains of Bacillus were isolated from the maternal line J72464, 4 strains of Bacillus were isolated from the progeny JMC121; 11 strains of Bacillus $₫ 1$ strain of Curtobacterium and 1 strain of Arthrobacter were isolated from the maternal line JMC01, 11 strains of Bacillus were isolated from the progeny JN728; 12 strains of Bacillus and 9 strains of Pantoea were isolated from the maternal line J88, and 7 strains of Bacillus were isolated from the progeny JN828 (Supplementary Table 1). The dominant endophytic bacteria of the parental line and the F1 progeny were both Bacillus.

Based on the results of the 16S rDNA identification, the gyrA gene was used to further identify these Bacillus. The results showed Bacillus subtilis, Bacillus velezensis, Bacillus mojavensis, and Bacillus licheniformis were all existent in both the paternal line and the pollen. These four kinds of bacteria were 
all existed in the maternal line $\mathrm{J} 72464$ and only Bacillus subtilis and Bacillus mojavensis were found in the progeny JMC121. The maternal line JMC01 and its progeny JN728 both had these four kinds of Bacillus. There were three kinds of Bacillus in the maternal line J88囚including Bacillus subtilis, Bacillus velezensis, and Bacillus mojavensis, and the progeny $3 \mathrm{JN} 828$ had Bacillus subtilis, Bacillus velezensis, and Bacillus licheniformis. The specific results were shown in Supplementary Table 2. The Bacillus group of the progeny JMC121 and the progeny JN728 were the same as their parental lines. The Bacillus subtilis and Bacillus velezensis groups of the progeny JN828 were the same as its maternal line, and the Bacillus licheniformis groups of the progeny JN828was the same as its paternal line.

\section{RAPD molecular typing of Bacillus}

Based on the results of gyrA identification, RAPD molecular typing was used to identify the Bacillus species. The primers used in this study were OPA-02, OPA-18, OPL-07, and OPL-16. According to the electrophoresis results shown in Figure 2, J2416-7 in the paternal line, P10, P11, P12 in the pollen, and JN728-7, JN728-8 in the progeny JN728 were the same strain of Bacillus mojavensis. The Phylogenetic analysis of gyrA gene for these 6 strains of Bacillus mojavensis showed that they were the same strain (Figure 3).

\section{Bacillus with potential vertical transmission in hybrid maize}

According to the multiphase classification analysis, the dominant endophytic bacteria Bacillus of the paternal line and the maternal line could be passed to the progeny. RAPD molecular typing showed that the same strain of Bacillus mojavensis appeared in the paternal line, the pollen and the F1progeny, which meant that the dominant endophytic bacteria carried by paternal line could be transmitted from paternal line to progeny through the pollen.

\section{Discussion}

There are abundant microbial resources inside and on the surface of plant seeds, which contribute to the growth and development of plants. As a bridge between the parental line and the progeny, Plant seeds are responsible for passing beneficial microorganisms from generation to generation to achieve the purpose of directly or indirectly affecting plant growth and development, health, quality, yield and function (Khan et al., 2020).

In this study, the dominant endophytic bacteria were isolated from three groups of maize families that were the same paternal line. It was found that the dominant endophytic bacteria of maize seeds were mainly Bacillus and Pantoea. Li et al. (2021) found that Bacillus could improve the salinity tolerance of maize seed germination, and Bacillus could also affect seed germination (Chaurasia et al., 2020), resist drought stress (Moreno-Galván et al., 2020), and reduce maize's absorption of heavy metals (Afzal et al., 2020). Like the paternal line J2416, the dominant endophytic bacteria of pollen were Bacillus, including Bacillus subtilis, Bacillus velezensis, Bacillus mojavensis, and Bacillus licheniformis. The maternal line J72464 and JMC01 both had these four kinds of Bacillus, and the dominant endophytic bacteria of their 
corresponding F1 progeny were similar to their paternal line and maternal line. The Bacillus subtilis and the Bacillus velezensis in progeny JN828 were the same as their paternal line and maternal line, but the Bacillus licheniformis it contained was only the dominant endophytic bacteria of its paternal line. According to reports, Bacillus, Staphylococcus, and Corynebacterium were the dominant endophytic bacteria that can be cultivated in hybrid corn (Bodhankar et al., 2017). Gao et al. (2019) isolated the same strain endophytic Pantoea from maize in different geographical locations in northern China. Ikeda et al. (2013) studied the diversity of endophytic bacteria in the roots of three types of hybrid corn in Brazil. The study found that Pantoea, Bacillus, Burkholderia, and Klebsiella were their dominant endophytic bacteria, and there were differences in the endophytic bacteria colonized by hybrid genotypes and lineages. Based on high-throughput sequencing, Liu et al. (2020) studied the endophytic bacterial diversity of corn seeds with genetic relevance. They found that the dominant bacteria were Enterobacter, Shigella, Pseudomonas, Pantoea, Aeribacillus, Sphingomonas, and Halomonas, and the maternal line affected the endophytic bacterial diversity of hybrid seeds.

According to the RAPD molecular typing, one same strain of Bacillus mojavensis appeared simultaneously in the paternal line, the pollen and the progeny JN728, which proved that the dominant endophytic bacteria in the paternal line appeared in the pollen during plant growth, and it could inherit to the progeny accompanied by the flowering and fertilization process. As an important biocontrol bacterium (Rath et al., 2018), Bacillus mojavensis could produce plant growth regulator and assisted plants to resist abiotic stress (Bacon et al., 2006; Maheshwari et al., 2020). Vertical transmission ensures that the endophytic bacteria exist in the next generation of seeds (Shade et al., 2017; Cope-Selby et al., 2017). This vertical transmission can inhibit pathogenic microorganisms and support plant growth and development to achieve mutually beneficial symbiosis (Shade et al., 2017). The bacteria carried by seeds are an important source of the plant microbiome. When seeds germinate, the endophytic bacteria they carry absorb water, produce secretions, attract bacteria to form plant roots, and directly and indirectly promote plant growth and health (Figueiredo et al., 2021). Along with the growth of the plant, seed microorganisms will also enhance the stress resistance of the plant. As shown in figure 4, during the formation of progeny maize seeds, there are two main sources of endophytic bacteria carried by them. The first is the external horizontal transmission, which mainly comes from the growth environment of maize, including the roots obtain microorganisms from the soil environment when the seeds germinate, and the air environment and insects that the plant is in contact with when it grows (Wiewióra et al., 2015). The second is internal vertical transmission, which means progeny maize seeds inherit the dominant endophytic bacterial resources derived from their parent seeds. In previous reports, the vertical transmission is limited to maternal inheritance including two main ways. The first is the transmission through the xylem or non-vascular tissues of the maternal line plant, and the second is the transmission through the stigma of the maternal line plant during flowering (Shade et al., 2017). This study found that the vertical transmission of the patrilineal dominant endophytic bacteria was also an important source of endophytic bacteria in progeny maize seeds. The pollen transferred the patrilineal dominant endophytic bacteria to progeny through fertilization and acted on the germination and growth of progeny. However, 
this had only been observed in the exploration of diversity, and confirmation of colonization experiments will be carried out in the future.

\section{Declarations}

\section{Authors' Contributions}

Wu QY and Wang ZS designed and participated in all experimental procedures, performed data analysis, and drafted the manuscript. Zhang RY and Xu TJ participated in the plant samples cultivation, samples collection and preparation. Zhao JR and Liu Y supervised the study and critically revised the manuscript. All authors read and approved the final manuscript.

\section{Funding}

The research was supported by the Fundamental Research Funds for the Central Universities (No. FRFTP-20-044A2; FRF-BR-19-003B; FRF-MP-20-39).

\section{Availability of data and materials}

All data generated or analyzed during this study are included in this published article and its supplementary information files.

\section{Ethics approval and consent to participate}

Not applicable.

\section{Consent for publication}

Not applicable.

\section{Compliance with ethical standards}

This article does not contain any studies with human participants or animals performed by any of the authors.

\section{Conflict of interest}

The authors declare that they have no competing interests.

\section{References}

1. Afzal I, Shinwari ZK, Sikandar S, Shahzad S (2019) Plant beneficial endophytic bacteria: mechanisms, diversity, host range and genetic determinants. Microbiol Res 221: 36-49. https://doi.org/10.1016/j.micres.2019.02.001 
2. Afzal MJ, Khan MI, Cheema SA, Hussain S, Anwar-Ul-Haq M, Ali MH, Naveed M (2020) Combined application of Bacillus sp. MN-54 and phosphorus improved growth and reduced lead uptake by maize in the lead-contaminated soil. Environ Sci Pollut Res Int 27(35): 44528-44539. https://doi.org/10.1007/s11356-020-10372-4

3. Bacon CW, Hinton DM, Hinton A Jr (2006) Growth-inhibiting effects of concentrations of fusaric acid on the growth of Bacillus mojavensis and other biocontrol Bacillus species. J Appl Microbiol 100(1): 185-94. https://doi.org/10.1111/j.1365-2672.2005.02770.x.

4. Bodhankar S, Grover M, Hemanth S, Reddy G, Rasul S, Yadav SK, Desai S, Mallappa M, Mandapaka M, Srinivasarao C (2017) Maize seed endophytic bacteria: dominance of antagonistic, lytic enzymeproducing Bacillus spp. 3 Biotech 7(4): 232. https://doi.org/10.1007/s13205-017-0860-0

5. Chaurasia LK, Tamang B, Tirwa RK, Lepcha PL (2020) Influence of biosurfactant producing Bacillus tequilensis LK5.4 isolate of kinema, a fermented soybean, on seed germination and growth of maize (Zea mays L.). 3 Biotech 10(7): 297. https://doi.org/10.1007/s13205-020-02281-7

6. Chen ZB, Li B, Wang DK, Yu L, Xu SG, Ren Z, Jin S, Dai LJ (2016) Study on the diversity of endophytic bacteria in Maize using Illumina MiSeq High-throughput Sequencing system. Mod Food Sci Technol. https://doi.org/10.13982/j.mfst.1673-9078.2016.2.018

7. Cope-Selby N, Cookson A, Squance M, Donnison I, Flavell R, Farrar K (2017) Endophytic bacteria in Miscanthus seed: implications for germination, vertical inheritance of endophytes, plant evolution and breeding. GCB Bioen 9: 57-77. https://doi.org/10.1111/gcbb.12364

8. Figueiredo Dos Santos L, Fernandes Souta J, de Paula Soares C, Oliveira da Rocha L, Luiza Carvalho Santos M, Grativol C, Fernando Wurdig Roesch L, Lopes Olivares F (2021) Insights into the structure and role of seed-borne bacteriome during maize germination. FEMS Microbiol Ecol 97(4): fiab024. https://doi.org/10.1093/femsec/fiab024

9. Gao JL, Xue J, Yan H, Tong S, Sayyar Khan M, Wang LW, Mao XJ, Zhang X, Sun JG (2019) Pantoea endophytica sp. nov., novel endophytic bacteria isolated from maize planting in different geographic regions of northern China. Syst Appl Microbiol 42(4): 488-494.

https://doi.org/10.1016/j.syapm.2019.06.001

10. Ikeda AC, Bassani LL, Adamoski D, Stringari D, Cordeiro VK, Glienke C, Steffens MB, Hungria M, GalliTerasawa LV (2013) Morphological and genetic characterization of endophytic bacteria isolated from roots of different maize genotypes. Microb Ecol 65(1): 154-60. https://doi.org/10.1007/s00248012-0104-0

11. Khan MA, Asaf S, Khan AL, Adhikari A, Jan R, Ali S, Imran M, Kim KM, Lee IJ (2020) Plant growthpromoting endophytic bacteria augment growth and salinity tolerance in rice plants. Plant Biol (Stuttg) 22(5): 850-862. https://doi.org/10.1111/plb.13124

12. Lefevre $M$, Racedo $S M$, Denayrolles $M$, Ripert $G$, Desfougères $T$, Lobach $A R$, Simon R, Pélerin $F$, Jüsten P, Urdaci MC (2016) Safety assessment of Bacillus subtilis CU1 for use as a probiotic in humans. Regul Toxicol Pharmacol 83: 54-65. https://doi.org/10.1016/j.yrtph.2016.11.010 
13. Li H, Yue H, Li L, Liu Y, Zhang H, Wang J, Jiang X (2021) Seed biostimulant Bacillus sp. MGW9 improves the salt tolerance of maize during seed germination. AMB Express 11(1): 74. https://doi.org/10.1186/s13568-021-01237-1

14. Liu Y, Yan H, Zhang X, Zhang R, Li M, Xu T, Yang F, Zheng H, Zhao J (2020) Investigating the endophytic bacterial diversity and community structures in seeds of genetically related maize (Zea mays L.) genotypes. 3 Biotech 10(1): 27. https://doi.org/10.1007/s13205-019-2034-8

15. Liu Y, Zuo S, Xu L, Zou Y, Song W (2012) Study on diversity of endophytic bacterial communities in seeds of hybrid maize and their parental lines. Arch Microbiol 194(12): 1001-12. https://doi.org/10.1007/s00203-012-0836-8

16. Maheshwari R, Bhutani $N$, Suneja $P$ (2020) Isolation and characterization of ACC Deaminase Producing Endophytic Bacillus mojavensis PRN2 from Pisum sativum. Iran J Biotechnol 18(2): e2308. https://doi.org/10.30498/IJB.2020.137279.2308

17. Moreno-Galván A, Romero-Perdomo FA, Estrada-Bonilla G, Meneses CHSG, Bonilla RR, (2020) Drycaribbean Bacillus spp. strains ameliorate drought stress in maize by a strain-specific antioxidant response modulation. Microorganisms 8(6): 823. https://doi.org/10.3390/microorganisms 8060823

18. Rath M, Mitchell TR, Gold SE (2017) Volatiles produced by Bacillus mojavensis RRC101 act as plant growth modulators and are strongly culture-dependent. Microbiol Res 208: 76-84. https://doi.org/10.1016/j.micres.2017.12.014

19. Santos LF, Souta JF, Rocha LO, Soares CP, Santos MLC, Grativol C, Roesch LFW, Olivares FL (2021) Altered bacteria community dominance reduces tolerance to resident fungus and seed to seedling growth performance in maize (Zea mays L. var. DKB 177). Microbiol Res 243: 126643. https://doi.org/10.1016/j.micres.2020.126643

20. Shade A, Jacques MA, Barret M (2017) Ecological patterns of seed microbiome diversity, transmission, and assembly. Curr Opin Microbiol 37: 15-22. https://doi.org/10.1016/j.mib.2017.03.010

21. Singh S, Singh UB, Trivedi M, Sahu PK, Paul S, Paul D, Saxena AK (2019) Seed biopriming with salttolerant endophytic Pseudomonas geniculate-modulated biochemical responses provide ecological fitness in maize (Zea mays L.) grown in saline sodic soil. Int J Environ Res Public Health 17(1): 253. https://doi.org/10.3390/ijerph17010253

22. Singh S, Singh UB, Malviya D, Paul S, Sahu PK, Trivedi M, Paul D, Saxena AK (2020) Seed biopriming with microbial inoculant triggers local and systemic defense responses against rhizoctonia solani causing banded leaf and sheath blight in maize (Zea mays L.). Int J Environ Res Public Health 17(4): 1396. https://doi.org/10.3390/ijerph17041396

23. Taulé C, Vaz-Jauri P, Battistoni $F$ (2021) Insights into the early stages of plant-endophytic bacteria interaction. World J Microbiol Biotechnol 37(1): 13. https://doi.org/10.1007/s11274-020-02966-4

24. Wang Z, Zhu Y, Li N, Liu H, Zheng H, Wang W, Liu Y (2021) High-throughput sequencing-based analysis of the composition and diversity of endophytic bacterial community in seeds of saline-alkali tolerant rice. Microbiol Res 250: 126794. https://doi.org/10.1016/j.micres.2021.126794 
25. Wiewióra B, Żurek G, Pańka D (2015) Is the vertical transmission of neotyphodium lolii in perennial ryegrass the only possible way to the spread of endophytes? PLoS One 10(2): e0117231. https://doi.org/10.1371/journal.pone.0117231

26. Wu X, Jiang Q, Wang Z, Xu Y, Chen W, Sun J, Liu Y (2021) Diversity, enzyme production and antibacterial activity of Bacillus strains isolated from sesame-flavored liquor Daqu. Arch Microbiol 203(9): 5831-5839. https://doi.org/10.1007/s00203-021-02552-8

27. Yang F, Zhang R, Wu X, Xu T, Ahmad S, Zhang X, Zhao J, Liu Y (2020) An endophytic strain of the genus Bacillus isolated from the seeds of maize (Zea mays $L$.) has antagonistic activity against maize pathogenic strains. Microb Pathog 142: 104074.

https://doi.org/10.1016/j.micpath.2020.104074

\section{Figures}

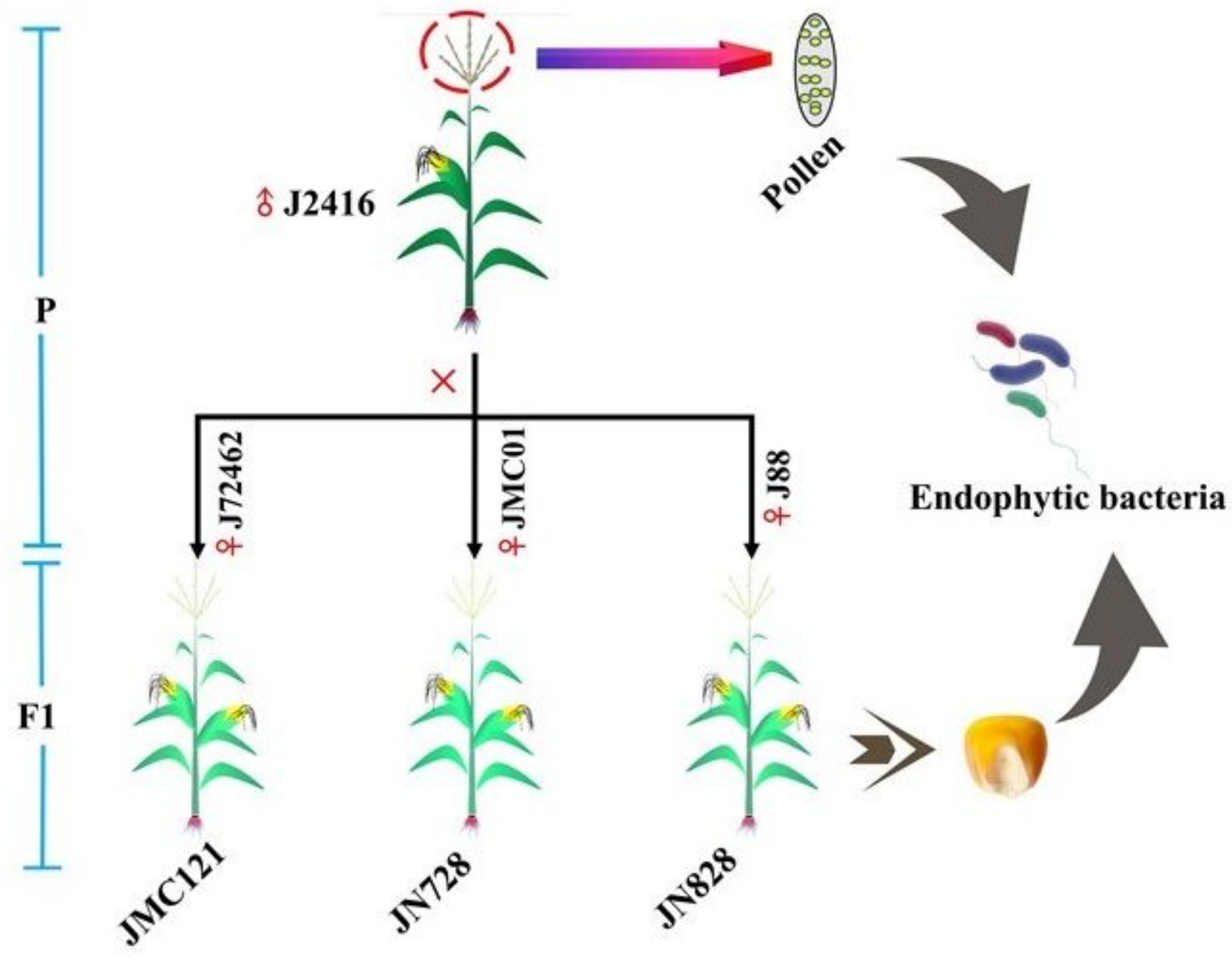

Figure 1 
Hybrid maize selected for this study. The common paternal line J2416 and its pollen, the maternal line $\mathrm{J} 72464$ and its progeny JMC121, the maternal line JMC01 and its progeny JN728, and the maternal line J88 and its progeny JN828.

A

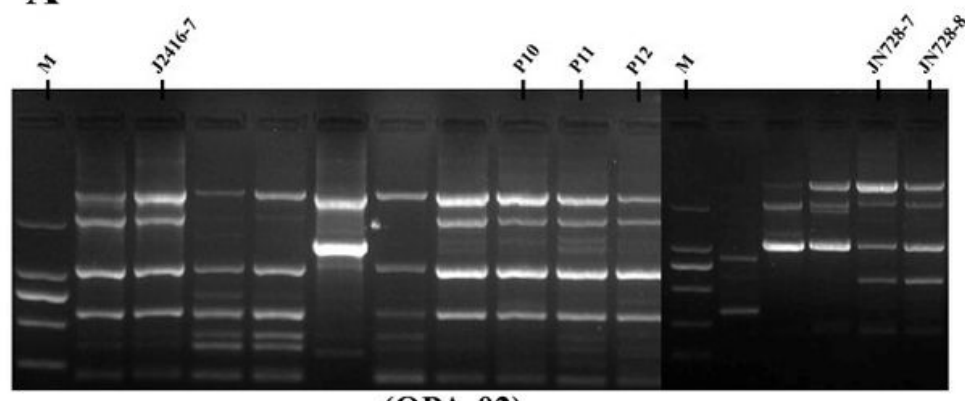

(OPA-02)

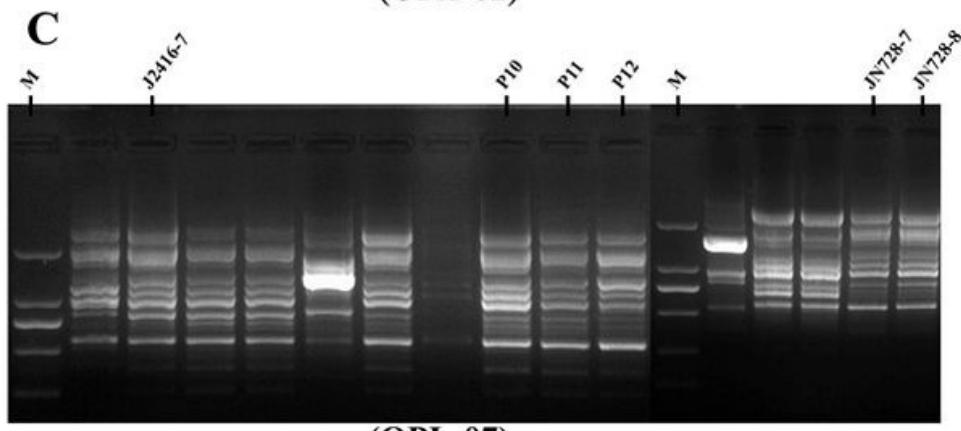

(OPL-07)
B

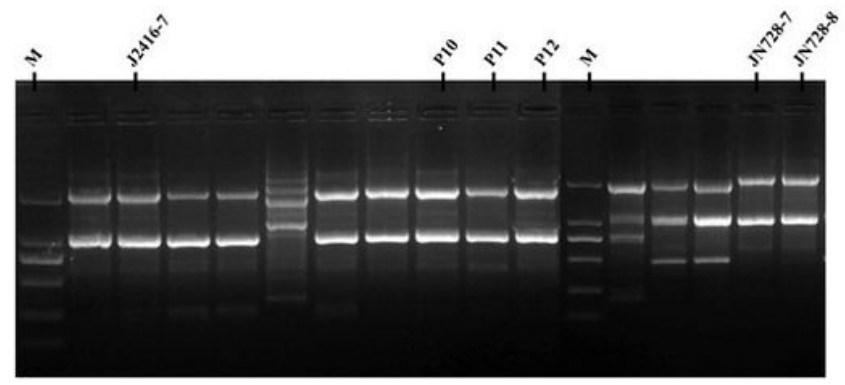

(OPA-18)

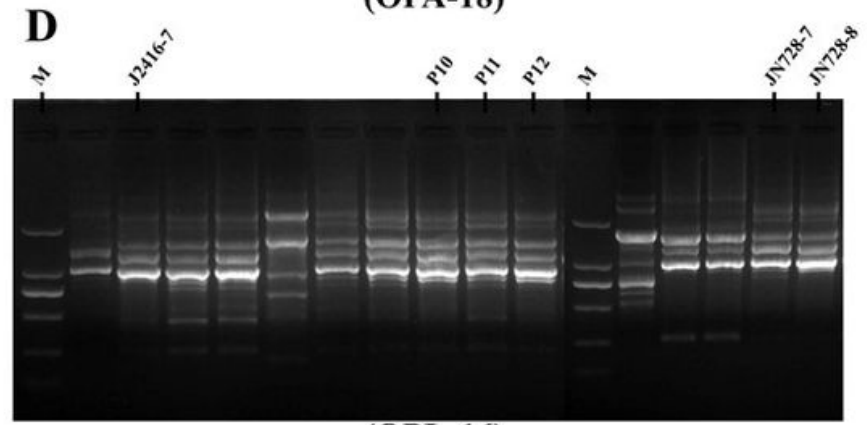

(OPL-16)

\section{Figure 2}

Schematic diagram of Bacillus RAPD molecular typing. According to the amplification of 4 random sequences, J2416-7 in the paternal line, P10, P11, P12 in the pollen, and JN728-7, JN728-8 in the progeny JN728 were the same strain of Bacillus mojavensis. 


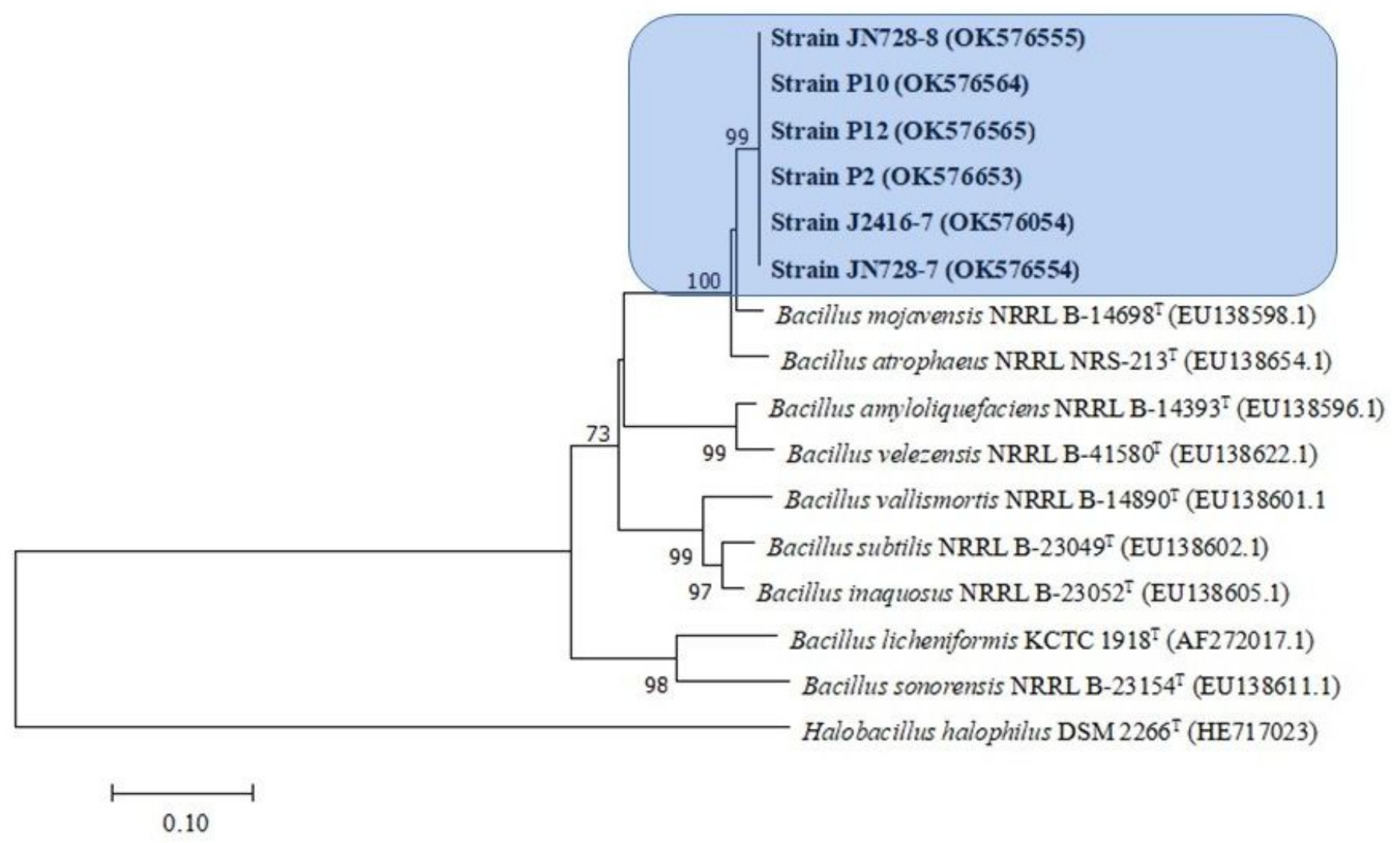

Figure 3

Phylogenetic analysis of gyrA gene showed that 6 strains of Bacillus mojavensis from the paternal line $\mathrm{J} 2416$, the pollen and the progeny JN728 were clustered together. The scale bar indicated 0.10 substitutions per nucleotide position. 


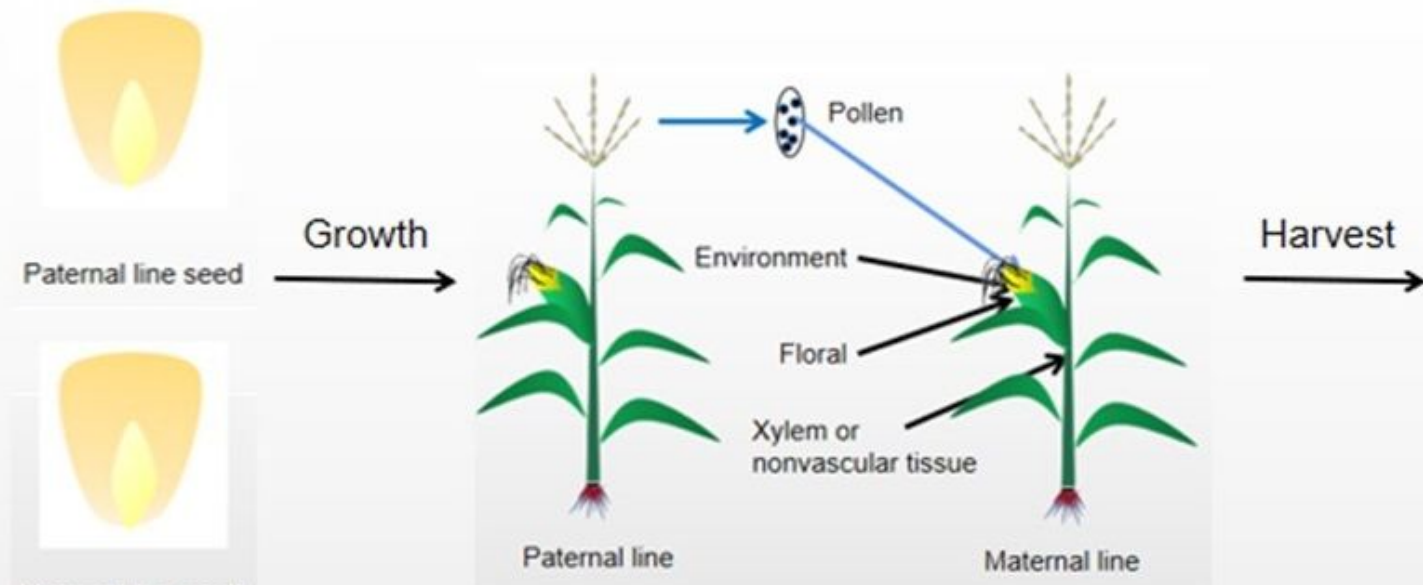

\section{Figure 4}

The source of seed microorganisms in the process of corn seed formation. The horizontal inheritance and the vertical transmission based on the maternal parent have been confirmed. The blue arrow indicates the vertical transmission based on the paternal line, which was related to this study.

\section{Supplementary Files}

This is a list of supplementary files associated with this preprint. Click to download.

- supplementaryTableR1.docx 